\title{
The State of Food (In)Security in the Trans-Himalaya, Upper-Mustang, Nepal
}

Rishikesh Pandey

\begin{abstract}
Food insecurity is a global issue, with higher prevalence of hunger in developing countries. Low crop yield and food production - due to difficult topography and traditional farming methods - combined with lower income; fluctuations in prices and supply, and low quality of food have been causing food insecurity in Nepal. This research examines food (in)security situation in Upper-Mustang, Nepal. The results are derived from the data collected through face-to-face interviews with the heads of 66 households, in-depth interviews conducted with 22 key informants, and discussions with the group of local people in different (6) places. The household food system was studied from livelihood perspectives and food (in) security was assessed in relation to self-sufficiency or production sufficiency, access, utilization, and stability of food. Households in the Trans-Himalaya acquire food from multiple sources such as farming and livestock ranching, buy food from the market, and also receive food aid for the sake of survival during the food crisis. Food security situation in terms of self-production in Upper-Mustang is at worst stage that many households are facing severe to chronic food insecurity. Studied households access marketed food, though the price they pay is very high. The worrisome issue is that there is no significant improvement in food security situation over time in the Trans-Himalaya. Study found that not the household size but dependency ratio in the household increases food insecurity. On the other hand, quality of farmland in terms of cropping intensity and availability of irrigation rather than the farm-plot size contribute for food security. The issue of food security is still a valid development
\end{abstract}


policy goal for Nepal in general and for the Trans-Himalaya in particular. Accordingly, food security interventions are important. Yet, policy for interventions should look into all components of food systems, particularly providing irrigation, promoting local food varieties, and provisioning for food subsidies and food aid together with subsidies in food transport.

Keywords: food security, HFIAS, Trans-Himalaya, UpperMustang, Nepal

\section{Introduction}

Populations suffering from undernourishment and chronic hunger are on rise globally, nevertheless the problem is particularly severe in the low-income countries like Nepal. One in every sixth person in the world is undernourished (FAO, 2009). The World Bank's data in 2011 show South Asia as a home of poor since over $60 \%$ people in the region are poor in terms of $\$ 2 /$ day income. Out of the total, $56 \%$ of population were poor in 2010 in Nepal in reference to $\$ 2 /$ day income threshold ${ }^{1}$ (WB, 2015a). The level of absolute poverty in the country was $25 \%$ in 2012 (CBS-NLSS, 2012). The country is ranked $57^{\text {th }}$ in Global Hunger Index (GHI) with GHI value of 19.8, depicting alarming situation of hunger (IFPRI, 2009) in Nepal. The worrisome issue is that almost one-third population of the country spent their $75 \%$ of income on food while over $55 \%$ spent $65 \%$ of their income for the same (CBS et al., 2013). In general, over a quarter of populations of Nepal are considered to be food poor, while over a half of children under the age of 5 years suffer from chronic undernutrition (CBS-NLSS, 2012); inhibiting close link between poverty and food insecurity in Nepal.

Geographically, Nepal is very complex, which in turn has caused reduced access to farmland, limited opportunities for agricultural modernization, and limited per capita farmland to its farmers. Over $93 \%$ farming households are marginal $(51.8 \%)$ and small $(41.3 \%)$ holders in terms of land holding who hold less than 0.5 hectare (ha), and 2 ha of land in average respectively (CBS, 2013a). Furthermore, the Trans-Himalaya has even limited arable land as well as limited growing season. The region is characterised by high levels of risk

1. Viewed 17 July, $2015<$ http://povertydata.worldbank.org/poverty/region/SAS> 


\section{4| Rishikesh Pandey}

and vulnerability associated with geographical process of mountain dynamism, weather related extreme events, and socioeconomic constraints; which are the factors causing the lowest per unit of agricultural production.

Length of growing season, agricultural potential, food production, food consumption, food import, and food distribution implicate food security (Yu \& You, 2013). Different ecological zones of Nepal have variable length of growing seasons, agricultural potentialities, irrigability of farmland, and land suitability for farming. Such variations have differentiated production of cereal crops, distribution mechanisms of food and store as well as handling of food grain. Such elements in turn, promoted disparity in food security outcomes. Among the three ecological zones of Nepal, Himalayan region produces only three-fourths of food required for the region or only, in other words it produces only $6 \%$ share of country's production (Regmi, 2007) while the region accommodates about $8 \%$ of country's population.

In the global context, famines have gradually become less frequent, and physical and economic access to food has generally increased (FAO et al., 2013). Nepal used to be a food secure country just few decades earlier, however, food import is increasing rapidly recently (CBS, 2013b). In this context, it is important to develop understanding on agriculture and livelihood systems of Nepal and look for potential food (in)security outcomes across the country so necessary policy intervention could be made to address the growing problem of food insecurity in the country. In this context, this research assesses the situation of food (in)security in the TransHimalaya in reference to the situation manifested in Upper-Mustang, Nepal. This research answers four research questions: whether the small farmers of the Upper-Mustang, who are dominantly producerconsumer, have food self-sufficiency? If they do not produce enough food for the households, what is the state of food access (economic)? What is the food security situation upper-Mustang in relation to utilization and stability? Is the food (in)security situation of the region changing over time? The answers of these questions provide feedback for food security policy in Nepal in general and for food deficit communities of the Trans-Himalaya in particular. 


\section{Dhaulagiri Journal of Sociology and Anthropology Vol. 10, $2016 \mid 95$}

This paper is divided into six sections. The first section has introduced the study theme and has framed the study aims. The second section conceptualises the issue of food security while third section describes adopted research methods and used materials to reach to the conclusion. The fourth section provides results of the study. The results are further summarised in relation to existing scholarship in discussion section to validate the study findings. The last section provides concluding statements.

\section{Conceptualizing Food Security}

Food security is a multi-dimensional concept. The meaning of food security differs across the social, cultural, and politico-economic environments. In general, food security is a function of food system - the mechanisms of achieving the goal of food security (FAO, 2008). Food system incorporates dynamic interactions of the elements of the biogeographical and human environments involved in production - processing - preparation - consumption of food (Gregory et al., 2005). Food security is a compound concept. There exist numerous definitions of food security. For examples, the International Food Policy Research Institute (IFPR) has listed over two hundreds definitions of food security (IFPRI, 1999). However, food security in general refers to a situation when all people at all times have both physical and economic access to sufficient, safe and nutritious food to meet their dietary needs and food preferences for an active, productive and healthy life (USAID, 1992; WFS, 1996). This definition, nevertheless, does not incorporate some of the important elements of food system and security associated with demographic, socio-cultural, and physical environment.

In recent decades, understanding of food security has become wide. Food security is understood in a broader sense refers to the state of availability, access, utilization, and stability of food (FAO, 2008). In Nepali food policy, the concept, however, focuses on traditional measurement of food availability (domestic production and imports) and utilization (mostly limited in macronutrient consumption). There are many limitations in applying a broader concept of food security in the Nepali context, particularly because of the domination of producer-consumer, who consume what they produce. Therefore, food security in this paper specifically focuses to self-sufficiency 


\section{6| Rishikesh Pandey}

or adequate production (physical availability/quantity of food produces, stored, processed, consumer or exchanges); market access to food (affordability within the household income or without deficit in annual household budget); while utilization and stability or overall macro-nutrition outcomes measured by the Household Food (In)Security Access Scale (HFIAS) are also discussed.

\section{Food availability}

Food availability is physical quantity of food that is produced, stored, processed, consumed, or exchanged (FAO, 2008). In this paper, availability is particularly considered as self-sufficiency or production sufficiency at household level because dominant households of Upper-Mustang are producer-consumer, the geographic limitations of the region constraints for crop-varieties, and area's remoteness and inaccessibility increases the price of marketed food beyond the affordability of farming households.

\section{Access to food}

Access to food refers to food entitlement or adequate resources required for an individual and a household to acquire appropriate foods for a nutritious diet (Sen, 1989). The resources to acquire food are understood as alternative commodity bundles that a person or household can command in a society using the totality of rights and opportunities that he or she faces (Sen, 1984). According to the UN Food and Agriculture Organization, a person's ability of establishing command on resources in relation to the legal, political, economic and social arrangements of the community is understood as access (FAO, 2006). In this paper, the access is defined as households' ability to purchase food without deficit household budget and without compromising the resources required for other basic needs such as clothing, shelter, health and education.

\section{Utilization of food}

The utilization of food on the other hand indicates the securing the essential nutrients from consumed foods (FAO, 2008). Utilization is actual consumption in relation to processing, storing, use of food, and obtaining adequate nutrition in turn. The assessment of 
utilization of food is complex, yet this study applies the HFIAS scale to assess utilization and stability of food.

\section{Food stability}

Food stability as a whole refers to availability, access and utilization of food at all times (FAO, 2006) or no interruption in any components of food security. Although the concept of stability covers a wider aspect of food security; it has not sufficiently been practice in Nepal to assess food security. Formal measures of food security in Nepal as practiced by Central Bureau of Statistics et al. (2013, p.3) are: availability (mostly self-sufficiency or even grain sufficiency), access (ability to purchase) and utilization (macro-nutritional outcomes). This sort of practice is common to many Asian (poor?) countries (Jiang, 2008). The macro-nutritional outcomes are the results of different aspects of food security. The HFIAS scale has the ability to assess availability, access, utilization, and stability at once in general; therefore this study assesses food (in)security in the Trans-Himalaya, Upper-Mustang using following methods and materials.

\section{Study Area}

\section{Methods and Materials}

The Trans-Himalaya is the northern foothills of the Greater Himalaya and the southern frontier of the Tibetan plateau. Climatically, it is the rain-shadow of the Greater Himalaya. Consequently, the longterm annual average precipitation is only to $267 \mathrm{~mm}$ at Jomsom even though it is only about $30 \mathrm{~km}$ north of Lumle that gets over $5400 \mathrm{~mm}$ of annual rainfall (Pandey \& Bardsley, 2015). The region has the cool-temperate arid climate, however, frequently experiences the mid-latitude high pressure belts and extreme blizzards. The EastWest strip of the Trans-Himalaya in Nepal is interrupted by the Greater Himalaya and Manang-Mustang of which is the biggest block lies inside Nepal. The elevation of present study site, UpperMustang (Figure 1), ranges between 3000-4000masl (having human habitation). The region is sparsely populated so has 2456 (1294 females) people in 752 households with an average of 3.3 persons per household. The area is mostly barren and rugged so cultivated farmland is limited; however, small fields are managed almost as 


\section{8| Rishikesh Pandey}

fertile oases. Therefore, the place is called 'Mustang' that means 'fertile plain' in Mustangi dialects. Inhabitants are mostly known as Mustangies and include several social strata including Brahmin/ Kshetries, Gurungs, Ghales, Thakalies, yet, they are commonly known as Bhotes.

Upper-Mustang comprises subalpine scanty vegetation, alpine pastures and some planted orchards. The major economic activities are agro-livestock based, together with tourism (hospitality and trekking) and seasonal business (hawking of herbal medicine and precious stones) in other areas. The region has only one growing season, April to September. The source of household energy (for cooking) is firewood, although the hotels use Liquefied Petroleum Gas (LPG) for cooking. Some settlements have electricity but most do not. Almost all households have toilet facilities; modern flush toilets are available only in hotels.

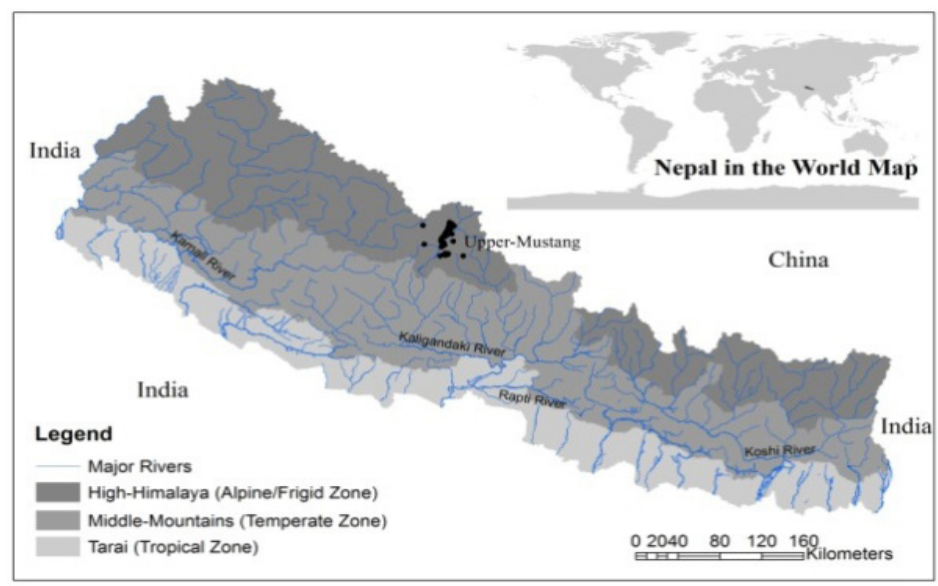

Figure 1: Map of Study Area - Nepal and Upper-Mustang 


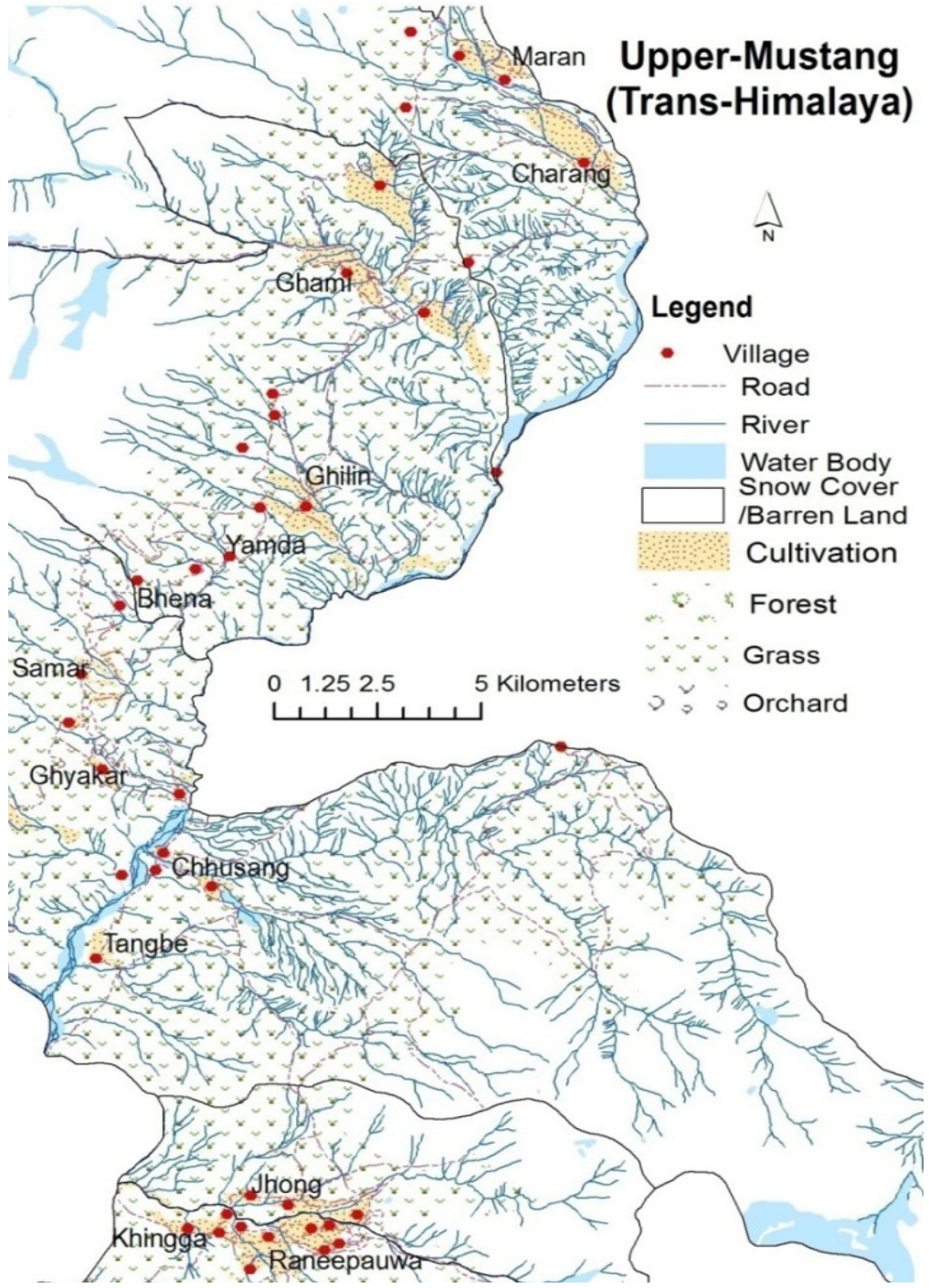

The studied VDCs of Upper-Mustang are connected by recently constructed seasonal unpaved roads. Public transport (jeep) is available occasionally if the weather is favourable. Jomsom is the nearest town, which is connected by air-route to Pokhara (city) and by seasonal road to Beni Bazaar (town centre). The region was isolated not only from the outer world but also from the mainstream societies and governance systems of Nepal for many years. Many 


\section{0| Rishikesh Pandey}

traditions of the Trans-Himalaya are common to Tibetan culture. Because of the area's remoteness and low population density, the place lacks effective basic services such as health and education.

\section{Sample Size}

A total of 66 households were sampled from 752 households of the area. Although 93 households were sampled initially using the formula $\mathrm{n}=\mathrm{n} 0 * \mathrm{~N} / \mathrm{n} 0+\mathrm{N}-1$ using $\mathrm{e}=1.0$ ( $10 \%$ error), level of significance $=0.05$ (95 percent confidence level), and estimated probability of success $(\mathrm{p})=50$ percent values; however, because of not getting consent from the head of sampled household and due to refusal of the respondents to participate in the research, only 66 interviews could be conducted under the planned budget and scheduled field-work time. In this sense, the level of confidence as of actual sample size is reduced to $91 \%$. To accumulate the rich data, in-depth interviews with 22 individuals and group discussions at 6 locations (different settlements) were conducted.

The information on public domain and common to the communities such as farming system, cereal production, seasonality, economic activities and general scenario of food security was collected at indepth interviews and focus group discussion; while data of private domain i.e. households' characteristics: social-demography and economic statuses of households, crop production, annual household budget along with data on household food security (in particular, 9 food utilization related questions, which the HFIAS method uses - see in annex) were collected at household levels using face-toface interview schedule with the heads of households. The author of this paper, with other two survey assistants having postgraduate qualification and adequate research experiences has conducted field work in close supervision of researcher so the standard of data quality is maintained. Furthermore, this research was conducted under the author's $\mathrm{PhD}$ project so the research followed standard code of conducts in doing research in human aspect. The author obtaining ethical clearance from the University of Adelaide, Australia and also is a certified researcher (Jointly Certified by the University of Adelaide, Flinders University, and the University of South Australia) for conducting research in human aspects. 


\section{Method of Analysis}

There are several methods of measuring food (in)security such as 'direct measure' or weights and heights, qualitative measure through peoples' perception of food (in)security. However, weight and height method is not very effective in explaining food (in)security since they are the outcome of long-term and complex interactions of consumed food and also vary across human genetics and other environmental factors. The qualitative measure is also not strong enough because different socio-cultural and economic backgrounds influence people's perceptions on food security. This study assessed food (in)security in relation to four parameters: Self-sufficiency, which is treated as 'availability', access to food (economic access - sufficiency of household annual budget), food utilization, and stability in terms of macro-nutritional outcome measured using the HFIAS scale.

\section{Household Food (In)Security Access Scale (HFIAS)}

The HFIAS was developed by the Food and Nutrition Technical Assistance (FANTA) Project, USA (Bilinsky \& Swindale, 2010; Coates, 2004; Coates et al.,2007). The HFIAS includes nine food security related questions (See Annex), which are categorised into three broad groups: anxiety and uncertainty in food supply; insufficient quality of food (food variety and preferred items); and impacts of food deficiency (insufficient food intake and its physical consequences). The respondents expressed level of deficiencies experienced on each of the questions in a 0 to 3 scale where ' 0 ' refers to 'no food deficiency', 1 = 'rare deficiency' (once or twice in a month), 2 = 'sometimes deficiency' (three to ten times deficiency in a month) and $3=$ 'often deficiency' (more than ten times in a month). The total score of a household, hence ranges from ' 0 ' ('no' responses in all of the 9 questions) to '27' ('often' responses in all of the questions), is the HFIAS for the household for particular month. Using this method, monthly scenario of food (in)security is obtained, which is transformed into an annual HFIAS later. Since this study has adopted Sen's theory of food entitlement ${ }^{2}$ (Sen, 1981) to express food (in)security; various sources of food the studied households

2. Food entitlement of a household is derived from their own production, the income, gathering of wild food, community supports, assets, and migration (Sen, 1981). 
command are discussed below to understand the sources of food in the Trans-Himalaya, Upper-Mustang, Nepal.

\section{Results}

\section{The Sources of Food for Households in Upper-Mustang}

The primary determinant of food security of farmers of the TransHimalaya is farming system, although the food security of farming households attached to multiple factors. The Trans-Himalayan farming system constitutes the 'variables' such as labour, cultivated fields, domesticated animals, forest and pastures (Aase et al., 2010). Here, labour force and occupation of population; economic status of households in relation to quantity and quality of farmland, monetary asset and livestock; and food items gathered from local forest are discussed as the sources of food for households to frame the foundation knowledge on food (in)security.

\section{Labour Force and Occupation}

Table 1 shows demographic characteristics of the studied households in Upper-Mustang. The population of males outnumber females. The household size is 5.9, which is higher than the national average of 4.9 persons (CBS, 2012). The proportion of dependent ${ }^{3}$ population is relatively high: $18.6 \%$ of the total population are children and $9.7 \%$ are aged.

Table 1: Demographic Characteristics of the Population in UpperMustang, Nepal

\section{Demographic Characteristics}

Number of Sample Households

Total Population

Male

Female

Household Size (person per household)

Sex Ratio (Number of male per 100 female)

Below 15 years of age ( $\%$ of total population)

$15-59$ years ( $\%$ of total population)

60 Years and above (\% of total population)

Dependency Ratio

\section{Values}

66

392

212

180

5.9

117.8

$18.6 \%$

$71.7 \%$

$9.7 \%$

39.5

Source: Field Survey, 2013

3. See the definition at end of paper 
The studied populations are engaged in a wide range of occupations. However, Nepali societies have a typical characteristic of reporting 'farming' (Krishi) as their principal occupation even if farming meets a small share to their annual food requirement. Figure 2 shows occupational status of studied population. Among the livelihood options, a combination of cropping and livestock is adopted by dominant proportions of population. Out of the total population $45.2 \%$ is engaged in agro-livestock activity. The proportion of the population engaged in paid labour is $12.2 \%$. The larger scope of tourism industry in Upper-Mustang has resulted in higher proportions of the population being engaged in business/entrepreneurship (8.2\%), particularly the hospitality business. Population going abroad as migrant labourer was $5.9 \%$, which is markedly higher than the national average of 0.07 percent 4 , although the low national figure is probably the result of poor recordings, as it is known that many Nepali do seek work abroad informally (Pandey \& Adhikari, 2013). A significant part of the population, mostly the young, are studying as well as helping with household chores, which is a typical practice in Nepali rural households that make it possible for working adults to allocate time for outdoor work and generate income or resources (Onta \& Resurreccion, 2011; Subedi \& Pandey, 2002; Subedi et al., 2007).

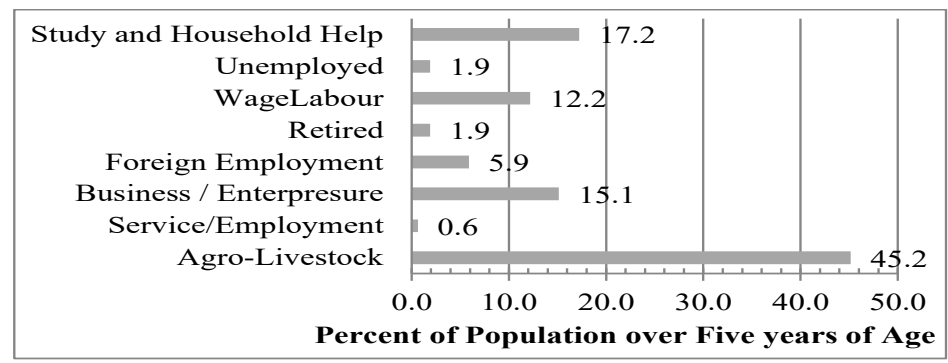

Figure 2: Occupational Status of Population by type of Occupation in Upper-Mustang, Nepal (Source: Field Survey, 2013)

4. labour migrant: 1445 inhabitants (World Bank Database as cited in $<$ http://www.ulandssekretariatet.dk/sites/default/files/uploads/public/PDF/ LMP/nepal_2013_final_web.pdf $>$ viewed on 19 October 2014. 


\section{4| Rishikesh Pandey}

\section{Land and Forest Resources}

Arable land is a vital resource for food security in Nepal. Oats, barley, wheat, potato, beans are the major crops grown in UpperMustang. Oats, barley, and wheat are cultivated in April - July season and while potato, maize, and buckwheat are cultivated in July - November season in lower elevation (at around 3000masl) while April/May - September/October is the only one growing season available for upper altitude. Particularly at Ghami village (above 3600masl) oat is only the single crop grown because of short growing season. Oat in some cases is sown in November and letting the winter snow covers it, which later germinates in March when snow starts melting, reported the research participants of group discussion at Tsusang and Ghami.

Inheritance practice land in Nepal has given access to land to $70.6 \%$ of the country's households (CBS 2013a). Even better situation in terms of access to land in Upper-Mustang is observed that almost all households reported having some land. Yet, there is a predominance of marginal and small holders (Table 2). Over 56\% households have of the study area has marginal size of holding, i.e. less than 0.5 ha. The proportions of small holders, having land between 0.5 and 2.0 hectares are $40.9 \%$. The mean size of land holding was 0.73 ha in the study area; nevertheless, there is a notable variation in size of holding across the households that standard deviations of $0.68 \mathrm{ha}$ is observed. In such a limited size of farm-plot with limited growing season, households have a big challenge to secure food from farming activities for relatively larger households.

Table 2: Proportion of Households by Holding Size in Upper-Mustang, Nepal

\begin{tabular}{lc}
\multicolumn{1}{c}{ Holding Size } & Proportion of Household \\
\hline Marginal Holders $(<0.5 \mathrm{ha})$ & 56.1 \\
Small Holders $(0.5-2 \mathrm{ha})$ & 40.9 \\
Medium Holders $(2-4 \mathrm{ha})$ & 3.0 \\
\hline
\end{tabular}

Source: Field Survey, 2013

The quality of land in terms of cropping intensity is poor in UpperMustang. The place is favourable only for single crop in a year. Farmers are making efforts to increase cropping intensities in low 
lands; as a result, actual cropping intensity stands at $138.1 \%$. Over $90 \%$ of farmland in the study area has irrigation during the growing season (Figure 3).

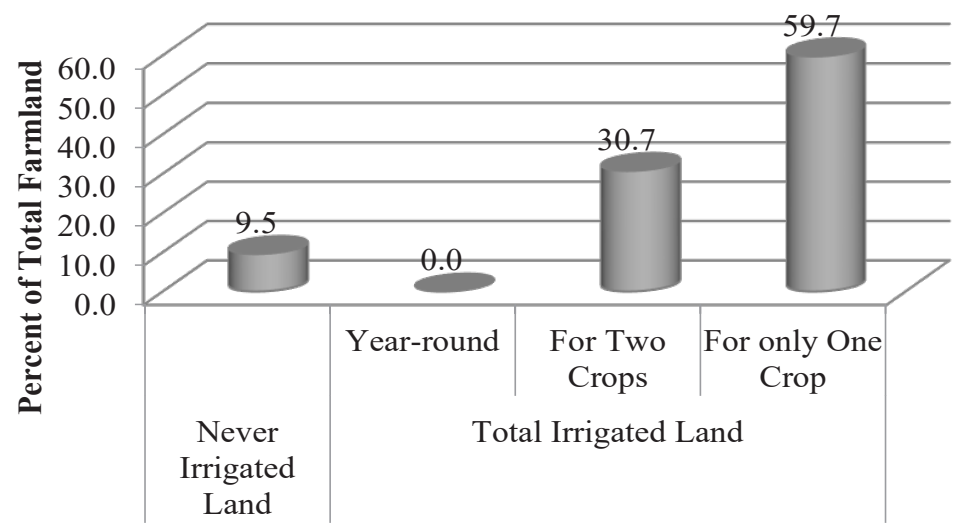

Availability of Irrigation

Figure 3: Status of Irrigation in Upper-Mustang, Nepal

(Source: Field Survey, 2013)

Wild edible plants provide staple and supplement foods, as well as cash income to local communities. Researchers found that forest supplies a sizable portion of food for rural farming households of Nepal (Ephrosine, 1994; Koirala, 2006; Rijal, 2010-2011; Subedi \& Pandey, 2002). Uprety et al. (2012) documented 44 species of edible fruits and 36 species of edible vegetables that local communities in Nepal have identified and are including in their food items, although such traditional knowledge is eroding throughout the country. The case of the Trans-Himalaya is different than that of other places in Nepal that limited availability of edible items due to harsh climatic conditions has reduced the scope of forest food collection in UpperMustang.

\section{Monetary Assets and Livestock}

The stock and flow of monetary assets is markedly weak in UpperMustang. None of the households reported financial investment in productive sectors; rather, nearly $14 \%$ respondents reported their indebtedness. The loan taken by households was spent to support 


\section{6| Rishikesh Pandey}

livelihoods. In addition, livestock is integral part of households' livelihoods in the Trans-Himalaya. Livestock supplies dairy and meat products for domestic consumption; supplies manure for better farm production; and households can earn cash by selling them. The participants of group discussion at Ghami (code 30001) mentioned ... livestock ranching and business are the major livelihood support options after farming in the place, major livestock kept in the place are mountain goat (Chyangra) ... Households of Upper-Mustang mostly keep cows, mountain goats, sheep, horses and mules, and Yaks/Jhocpos ${ }^{5}$. Horses and mules are the means of transportation in the Trans-Himalaya so they earn cash to support livelihoods.

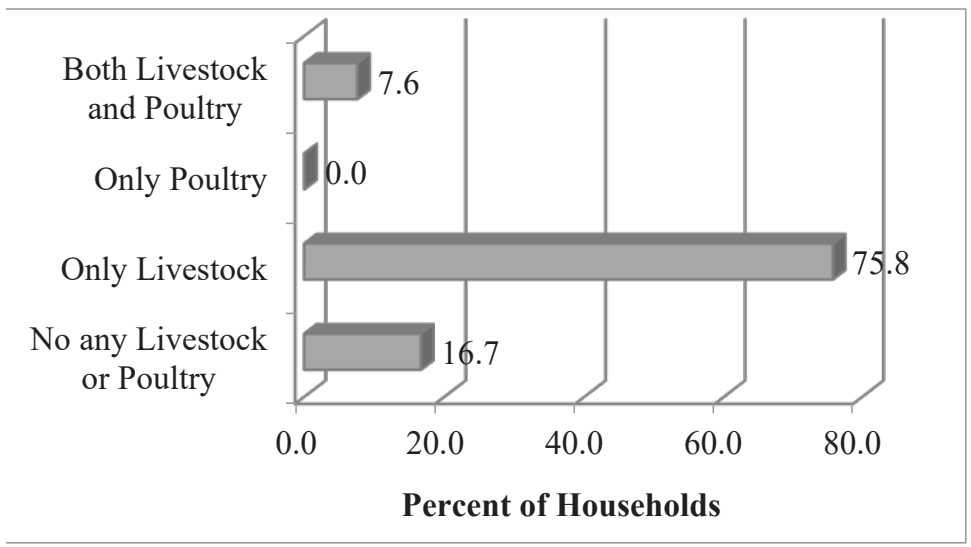

Figure 4: Proportion of Households with Livestock and Poultry in Upper-Mustang, Nepal

(Source: Field Survey, 2013)

Mountain goats and sheep on the other are major sources of cash income ${ }^{6}$ for the Mustangi households that later can be used to access marketed food. Higher numbers of mountain goats and/or sheep substantially increase the economic status of a household ${ }^{7}$ However,

5. Jhocpo is a cross breed of cow and yak that can adapt in high altitude as well as lower altitude 3000 to $3900 \mathrm{amsl}$.

6. The local free range chicken meat costs more than NPR500 (\$6)/kg and the male goat (mutton) costs over US $\$ 7 / \mathrm{kg}$, a milking buffalo costs about NPR60000 (\$650), and a high breed milking cow costs about NPR80000 (\$850).

7. Some of the households in the Trans-Himalaya own over 250 mountain goats, an accumulation of about 3.75 million Nepalese Rupees (US\$37500), 
since livestock is not insured in the study area, this form of wealth creation is not risk free, particularly in climate extremes of the Trans-Himalaya. In the next section, status of food (in)security and its dynamics over time in the Trans-Himalaya, Upper-Mustang is presented.

\section{Food (In)Security}

\section{Food Self-Sufficiency (availability)}

Food self-sufficiency is a major indicator of food security. Many households in Upper-Mustang reported no remarkable interruption in the supply of food in the market as far as a household has an economic access to food. Respondents of Tsusang during the group discussion (Code 30005) stated ... if we have money to buy, there is no shortage of food or any other things in the market.... Nevertheless, price of marketed food in the Trans-Himalaya is rather high because of areas inaccessibility and remoteness. The KII at Tsusang (code 3047) reported "... there is no meaning of providing subsidised food for us in the regional headquarter - Pokhara, as we cannot afford transportation cost..." Similar opinion was also stated by another respondent of Zhong (code 3027) “... government provides some rice but not of good quality, transportation cost makes that rather expensive so the cost is not much different than the price of the marketed rice ..." For this reason, this study considers selfsufficiency or production sufficiency as a primary measure of food availability in the Trans-Himalaya.

The statuses of food sufficiency vary across the studied households. The households are categorised into five classes (Table 3): households with no food deficiency, little (deficiency of up to $25 \%$ in annual food requirement), moderate (deficiency of up to $50 \%$ in annual food requirement), severe (deficiency of up to $75 \%$ in annual food requirement) and profound food deficiency (deficiency of over 75\% in annual food requirement). Out of the total households participated in the study, 39.4\% have reported food sufficiency (no deficiency). Among others, 3\% households reported profound shortage of food while $7.6 \%$ and $16.7 \%$ households reported severe and moderate levels of food deficiency, respectively. The finding of face-to-face

which is quite big in the context of Nepalese rural households. 


\section{8| Rishikesh Pandey}

interview at household level is further supported by group discussion at Ghami (code 30001) ... well-off farmer hardly produce grain for 6 months ... demonstrating notably poor status of food sufficiency in terms of household production in Upper-Mustang. The production of sufficient food required for the household is very important indicator of food security for the farming households; yet, many of them are unable to produce enough food. Accessing food from market is the option to those food deficient households to meet household food requirement.

\section{Sufficiency of annual household budget (access)}

In the study area, economic access to food (sufficiency of household annual budget without budget deficiency) is relatively better than the physical availability of food. Yet, some of the households experience different level of budget deficiency. Out of the total households, 3\% each experienced severe and moderate levels of deficiency (deficit) in annual household budget, while remarkably high proportion i.e. $37.9 \%$ households reported little deficiency in annual household budget (Table 3 ) particularly because of accessing marketed food. To meet the household food requirement, many houses have compromised the expenses on other basic needs such as clothing, health, and education as well as household appliances.

Table 3: Proportion of Households by levels of Annual

Food Deficiency and Annual Deficiency of Cash Requirement in Upper-Mustang, Nepal

\begin{tabular}{lrr}
\hline $\begin{array}{l}\text { Levels of Deficiency(\% of } \\
\text { annual requirement) }\end{array}$ & $\begin{array}{r}\text { Food } \\
\text { Deficiency (\% } \\
\text { of Households) }\end{array}$ & $\begin{array}{r}\text { Budget } \\
\text { Deficiency (\% } \\
\text { of Households) }\end{array}$ \\
\hline $\begin{array}{l}\text { Deficit of Less than 25\% } \\
\text { (Little) }\end{array}$ & 33.3 & 37.9 \\
$\begin{array}{l}\text { Deficit of Up to 50\% } \\
\text { (Moderate) }\end{array}$ & 16.7 & 3 \\
$\begin{array}{l}\text { Deficit of Up to 75\% (Severe) } \\
\text { Deficit of Over 75\% (Profound) }\end{array}$ & 7.6 & 3 \\
\hline
\end{tabular}

Source: Field Survey, 2013

The transportation cost of goods in the Upper-Mustang is notably 
high. One of the KII at Puran Gau, Muktinath (Code 3015) reported "... Government provides 3-4 quintal of subsidized food (rice and wheat) and salt to each household those do not have hotel business, however, transportation cost makes it similar to market price..." The KII at Zhong (Code 3027) also informed "... salt is provided in subsidized price and costs NRs.15/kg... (Similar to major cities in Nepal, Including in Kathmandu), whereas other things costs at least double in Lower Mustang than that of Kathmandu ..." The participants of group discussions at Tsusan (Code 3004, 3005) also reported ... government supports salt and rice. However rice becomes too expensive while paying the transportation cost. Also the quality of rice is so poor. For that reasons, households receive sufficient salt at subsidized price, not the rice... These information demonstrate the facts that food security situation in the Trans-Himalaya in terms of economic access is not much good as well.

\section{Food Security in terms of utilization and stability}

Food security, in its broader connotation, results from the availability of adequate food, effective consumption, and desirable nutrition outcomes (Ramachandran, 2006). This study assessed food utilization and stability in reference to macro-nutritional outcome of food consumption using a HFIAS scale. The HFIAS scale provides more robust method of assessing household food (in)security by incorporating the issues of availability, access, utilization and stability at the same time through bringing these components of food into an assessment system.

Table 4 shows state of food (in)security experienced by the studied households together with its chance over time (in the last decade). A half of the studied households have experienced food insecurity to some levels at present time. The problem of food deficiency is reported to be occasional for $42.4 \%$ households while it is moderately deficient in $7.6 \%$ households. Although notable proportions of households have faced food insecurity in Upper-Mustang, the severity of food deficiency, however, are declined in last one decade that the proportions of households without food deficiency climbed to $50 \%$ from $31.8 \%$ in 2003 while the proportions of households with occasional and moderate food deficiency are decreased to $42.4 \%$ and $7.6 \%$ from $59.1 \%$ and $9.1 \%$ respectively in the past decade. However, 


\section{0| Rishikesh Pandey}

the levels of food insecurity vary across the households that different proportions of households fall into different categories of food (in) security measures (Table 4), as well as the normalised HFIAS score (that sums the scores of each of the 9 food security related questions for an annum) also exhibits inter-household variations in food (in) security situation (Figure 5).

Table 4: Proportion of households with Level of Food (In)Security at Present and before 10 years (based on HFIAS Scale)

\section{Level of Food (In)Security}

No Food Deficiency (0 score in all questions)

Occasional Food Deficiency(1 score in all questions)

Moderate Food Deficiency (2 score in all questions)

Severe Food Deficiency (3 score in all questions)

Total

\section{Proportion of}

Households

\begin{tabular}{cc}
\hline $\begin{array}{c}\text { At } \\
\text { Present } \\
50.0\end{array}$ & $\begin{array}{c}\text { 10 Years } \\
\text { before } \\
31.8\end{array}$ \\
42.4 & 59.1 \\
7.6 & 9.1 \\
0.0 & 0.0 \\
$\mathbf{1 0 0}$ & $\mathbf{1 0 0}$ \\
\hline
\end{tabular}

Source: Field Survey, 2013

Various factors implicate household food security. Because the households are variably affected by the factors those implicate food security - such as access to land and household food production, access to income and marketed food, and access to social and political power that determines access to subsidised food or external support for agriculture. The variations in such elements in turn have caused inter-household variability in food sufficiency in UpperMustang (Figure: 5). 


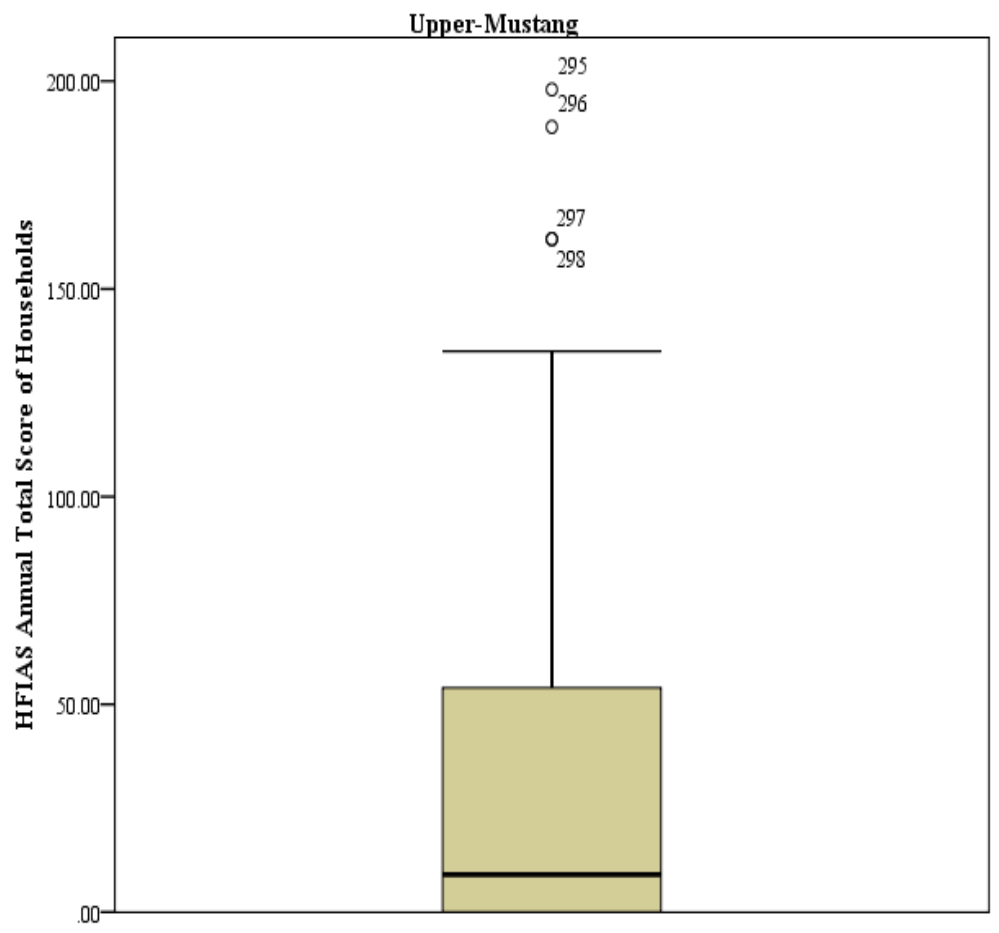

Figure 5: Inter-Household variation in Food (In)Security in UpperMustang, Nepal 2013.

Source: Computed from the data collected from the field

This paper has investigates relationship of household size, households' dependency ratio and arable land to food (in)security i.e. HFIAS scale (Table 5). Although Maharjan and Joshi (2011) reported increase in the probability of being food insecure with increase in family size, this study however, found statistically significant opposite relationship (at 95\% confidence level) between household size and the HFIAS; reflecting the fact that larger household size not necessarily a problem for household food security. Contrary to this, dependency ratio is positively correlated with the HFIAS, (although not statistically significant), indicating higher dependency rate as a factor causing food insecurity. This result also suggests that the population classified by this study as dependent (below 15 years of age and above 60 years of age) seem to be economically active. 


\section{2| Rishikesh Pandey}

Table 5: Correlation-Coefficient of Household Food Insecurity Access Scale with various Household Characteristics in Upper-Mustang, Nepal

Household Characteristics

Household Size

Household Dependency Ratio

Household Land Resources (Standardised -0.016 Indexed Value)

HFIAS 10 Years Before
HFIAS at

Present

$-0.260 *$

0.177

$0.807 * *$

Note: ** Correlation is significant at the 0.01 level, *Correlation is significant at the 0.05 level (2-tailed).

Better farm productivity and higher cropping intensity might help food security. However, only one growing season in UpperMustang might have caused weak relationship between the farmland index and HFIAS scale. From the results, it is possible to conclude that not the size of farmland but its quality in terms of cropping intensity and availability of irrigation, contribute for food security. More importantly, although some improvement in the food security situation over time is observed in Table 4; the change is not significant since there exists statistically significant positive correlation between the HFIAS score of 10 years ago and at present. It represent that food insecurity in Upper-Mustang is static and the state of Nepal has not perform well in addressing the issue of food insecurity, particularly in the Trans-Himalaya. As discussed earlier that transportation (that increases the price of marketed food) is a major factor worsening food insecurity in Upper-Mustang, other elements such as market failure and agro-ecological implications of climate change, as well as inflation might have playing the role in unstable availability and access to food in the Trans-Himalaya, although detail investigation in these sectors require further study.

\section{Discussion}

The livelihoods of Trans-Himalayan communities of UpperMustang, Nepal is derived mostly through primary resources of nature such as land, further supported through employment, small business, and remittances. The people of Upper-Mustang acquire food from self-production and market (see 4.2.1 and 4.2.2 sections 
above). A Female KII at Jharkot, Muktinath (age 60) stated that “... if any months, I lack food, neighbour lend for short period, until remittance send by my son and daughter arrives ..." reflecting the role of remittance in food security. Nevertheless, despite applying multiple resources, the households' food systems in the TransHimalayan are simply insecure, in terms of self-sufficiency, access, utilization, and stability. Limited growing season, small farm size are causing households suffer from food deficiency from selfproduction, while poor affordability of marketed food due to areas inaccessibility and remoteness reduced economic access to food, and no notable subsidies provided by the state in marketed food are causing food deficiency. Nevertheless, access to food is relatively better than that of production sufficiency (see Table 3). The macronutritional outcomes measured by the HFIAS scale, further shows that almost a half of the households of Upper-Mustang experienced some levels of food deficiency, and the problem is static in general in the last decade (see Table 5).

Not many studies on food (in)security conducted in Nepal have used a HFIAS scale method to assess state of food security. Therefore, it is difficult to link the findings of this research with other works of the field. Among the few available studies, Kular et al. (2013) applied the method and found moderate to severe level of food insecurity in $8.6 \%$ households of Nepal. The findings of present study reveal relatively less severe situation in the Trans-Himalaya. Nevertheless, the findings of present study in general are consistent tithe findings of Nepal Living Standard Survey 2010-2011 that has reported around $8 \%$ households of the country could not afford to eat one or more times a month (CBS-NLSS, 2012). On the contrary, Nepal Demographic and Health Survey (MOHP et al., 2012) showed notably higher proportions of households (over 50\%) as food insecure in the Central Tarai of Nepal. The severity of food insecurity situation in the Trans-Himalaya can be assumed to be much serious by the fact of food insecurity in the Tarai, the place with high cropping intensity, better irrigation, and the place being considered as 'the granary of the country'.

The net food import of Nepal is ever increasing, as a consequence, the country is losing out and has limited scope to reduce food price to improve access to food to poor. In addition, lower level 


\section{4| Rishikesh Pandey}

of access to cash income and increase of food price due to food transported from distant part also have caused higher food insecurity (economic access) in Upper-Mustang. The studied households are however, meeting their minimum food need from marketed food in no or minimum deficit of annual household budget (see Table 3), yet they are compromising the resources required for other basic needs such as clothing, shelter, health and education as well as household appliances to cope and adapt with the harsh Trans-Himalayan climate.

Food policy that was simply inappropriate for the rural Nepal is in practice since 1960 s, which has replaced local food items such as millet, buckwheat and other traditional food sources that caused severe food insecurity in north-western mountains of Nepal (Adhikari, 2008; Gaire et al., 2014). Although state interventions, particularly in the food systems of Upper-Mustang are recent, the modernization process has somehow implicated in the region that distant products rather than local are occupying the lunch/dinnerplates in Upper-Mustang as well. Together with these causes, food insecurity in Upper-Mustang is also associated with limited agricultural production caused by limited growing season and small size of farmland. Further, the households reported decreased livestock population in the area over time (Pandey 2016), which might have reduced the share of animal products in food items as well as income for marketed food in Upper-Mustang.

Food security is an outcome of a complex interaction between ecological, social, political and economic processes. In the background of poverty and underdevelopment in Nepal, a number of issues need to be addressed through integrated food and agriculture policies. Agricultural promotion and increase in production of cereal grain within the country is prominent option to overcome the issue of food insecurity in Nepal. The production-based entitlement, followed by fast growing of trade-based entitlement and partly inheritance and transferred entitlements (Sen, 1981:2) are the dominant practice of meeting food need in the Trans-Himalaya. In these contexts, effective agricultural policy is very urgent for Nepal.

Food security is one of the prominent indicators of household livelihood sustainability. Food insecurity is also reported to be 
associated with low human capital or poor livelihood assets (Lovendal, 2004). This paper analysed food security from livelihood perspective and found consistency with such claim. Therefore it can be suggested that increasing households income or strengthening households' livelihood capital that later can be translated to acquire food is vital strategy for households of Upper-Mustang. In addition to the policies to promote livelihood sustainability, effectively control of price, subsidised price for minimum requirement of food, and efficient transportation facility, yet environment friendly considering the sensitivity of Trans-Himalayan physiography, are necessary measures should be taken by the state to ensure food security in Upper-Mustang.

\section{Conclusion}

The state of food security in the Trans-Himalaya is assessed in terms of self-sufficiency of household food production, referred as availability in this paper; sufficiency of household budget to buy food from market, denoted as access to food; and utilization and stability of food in terms of macro-nutritional outcomes measured using the HFIAS scale. Food availability in the study area is poor, yet majority of households have access to marketed food to meet the minimum requirement for the households in general. The macronutritional outcomes show unfortunate situation that over a one-third households were identified to be suffered from moderate to severe levels of food insecurity (see Table 3 ). It is particularly due to limited cropping season and poorly available farmland, together with high price of marketed food, associated with area's inaccessibility and remoteness.

The studied households utilize different resources to meet household food requirement. Agro-livestock activity followed by labour migration and small business are the major sources of income those are positively contributing for food security through increasing the access to marketed food. Although food and livelihood security is still a valid development policy goal for Nepal in general and in the Trans-Himalaya in specific; promotion of local food production may not be adequate to meet the food need of the region particularly due to the ecological limits of the Trans-Himalaya. Nevertheless, adoption of integrated agriculture policy (crop-livestock, fruits 


\section{6| Rishikesh Pandey}

and vegetables, cash crops and production of medicinal herbs and their marketing) and encouraging households to reduce the share of food grain in daily food consumption and increasing the consumption of other items such as dairy and meat products, and fruit and vegetable, including potatoes; would support achieving food security in the Trans-Himalaya. In addition, the application of small scale technologies appropriate for mountain agriculture might increase food production and assist achieve sustainable food supply and overcome the problem of food insecurity in the Trans-Himalaya. Moreover, multi-layer agriculture using the greenhouse tunnels in limited fertile land can contribute for extra production and support for household food system. Furthermore, as it is identified that not the family size but the dependency ratio in the family affects food (in)security, policy should target for income generating activities for the labour forces surplus from existing agro-livestock system to achieve food security, together with provision for incentives for both older children and able elderly who are supporting agriculture despite their age-related limitations can be an appropriate statepolicy.

Not many studies in Nepal have adopted the HFIAS scale to assess food (in)security. The research participants of focus group discussion stated that the Trans-Himalayan environment supports very few crop-types therefore they consume what they produce. In this context, the question related to 'the varieties of food', the question used in HFIAS study, was not very relevant to this study. Similar to the government policy that does not emphasize for stability of food system to assess food security in Nepal; it is felt that the households of Upper-Mustang did not express food (in) security if they have something to solve hands-to-mouth problem. In addition, 'no deficiency' responses are also common in the questions associated with 'reduced amount of food intake' and 'escaping particular meal'. Although other researchers also used HFIAS method to assess food (in)security in rural context (see for example: Kular et al., 2013; McDonald et al., 2015); the HFIAS method found to be less effective tool to assess food security in Nepali, rural, producer-consumer households. Such situations warrants for the study of food (in)security from clinical perspective such as overall dietary management and supply of micro-nutrient, together with availability, access, utilization and stability of food 
to get a more reliable picture of the food (in)security in the TransHimalaya. Further research agenda could also include to investigate the strategies and their effectiveness the food insecure households adopting to meet household food need.

\section{Acknowledgements:}

The data used in this paper are collected under the author's $\mathrm{PhD}$ research project. The author would like to acknowledge Dr Douglas K Bardsley, The University of Adelaide, Australia for his generous guidance; The University of Adelaide for giving an opportunity to conduct this research; Pokhara University for providing study leave; and friends Pawan Chitrakar, Kamal Singh Thapa, Dharma Raj Parajuli, and Deependra Pandit for their help during the field work. Author also would like to acknowledge the anonyms reviewers of the paper and the editors of the journal for their munificent comments in the manuscript.

Dependency ratio $^{3}$ is defined as the ratio between economically active (working age population) mostly aged 15 to 59 years) and non-working population (aged below 15, and 60 and over) adopted by Central Bureau of Statistics, Nepal (CBS, 2012). Though, it has many limitations in terms of economic/livelihoods dependency. For an example, the remittance earners (retired and over 60 years of age) in many cases (retired military of British Gorkhas) may earn more than many of working age individuals and can bear the other dependent.

\section{Reference}

Aase, T.H.; Chaudhary, R.P. \& Vetaas, O. R. (2010). Farming flexibility and food security under climatic uncertainty: Manang, Nepal Himalaya. Area. 42 (2): 228-238. doi: 10.1111/j.1475-4762.2009.00911.x

Adhikari, J. (2008).Food crisis in Karnali: A historical and politico-economic perspective. Kathmandu: Martin Choutary. 


\section{8| Rishikesh Pandey}

Bilinsky, P. \& Swindale, A. (2010). Months of Adequate Household Food Provisioning (MAHFP) for Measurement of Household Food Access: Indicator Guide VERSION 4, Food and Nutrition Technical Assistance II Project (FANTA-2), NW Washington.

CBS (2012).National population and housing census 2011(National Report), vol. 1. Government of Nepal, Kathmandu: National Planning Commission Secretariat. CBS (2013a).National sample census of agriculture, Nepal 2011/12. Kathmandu: GoN/NPC/CBS.

CBS (2013b). Statistical Year Book 2013. Kathmandu: GoN/NPC/ CBS.

CBS, WFP, WB, AusAID \& UNICEF (2013). Nepal thematic report on food security and nutrition 2013. Kathmandu: Central Bureau of Statistics.

CBS-NLSS (2012).Nepal living standard survey 2010-2011, Statistical Report, vol. 2. Kathmandu: Central Bureau of Statistics.

Coates, J. (2004). Experience and expression of food insecurity across cultures: Practical implications for valid measurement. Food and Nutrition Technical Assistance Project (FANTA).Washington: Academy for Educational Development.

Coates, J.; Swindale, A, \& Bilinsky, P. (2007).Household Food Insecurity Access Scale (HFIAS) for Measurement of Food Access: Indicator Guide, VERSION 3, Food and Nutrition Technical Assistance Project (FANTA).Washington: Academy for Educational Development.

Ephrosine, D. (1994). Jungle resource use: Adaptive strategies of Rai and Sherpas in the Upper Arun Valley of Eastern Nepal. In M. Allen (eds.) Anthropology of Nepal: Peoples, problems and processes. Proceedings of an International Seminar on the Anthropology of Nepal: Peoples, Problems, and Processes, September 7-14, 1992 Kathmandu, Nepal. Kathmandu: Mandala Book point. pp. 49-63.

FAO (2006).Food security. FAO Policy Brief. Issue 2, June.

FAO (2008). Climate change and food security: A framework document. Interdepartmental working group on climate change. Rome: Food and Agriculture Organization of the United Nations.

FAO (2009). More people than ever are victims of hunger. FAO food outlook and background note on hunger. Rome: Food and Agriculture Organization of the United Nations 
FAO, IFAD, \& WFP (2013). The state of food insecurity in the world 2013: The multiple dimensions of food security. Rome: Food and Agriculture Organisation of the United Nations

Gaire, K.; Beilin, R. \& Miller, F. (2014). Withdrawing, resisting, maintaining and adapting: Food security and vulnerability in Jumla, Nepal. Regional Environmental Change. doi: 10.1007/s10113-014-0724-7.

Gregory, P.J.; Ingram, J.S.I. \& Brklacich, M. (2005).Climate change and food security. Transactions of the Royal Society B: Biological Sciences. 360: 2139-2148.

IFPRI (2009).Global hunger index. The challenge of hunger. The focus on financial crisis and gender Inequality. Washington DC: International Food Policy Research Institute.

IFPRI (1999).Technical guide for operationalizing household food security in development projects. Washington DC: International Food Policy Research Institute.

Jiang, T. (2008).WTO accession and food security in China. In C.

Chen \& R.Duncam (eds.). Agriculture and food security in China. Canberra: The Australian National University E Press and Asia Pacific Press. pp. 183-202.

Koirala, H. (2006). Livelihood pattern, adaptive strategy and sustainability of communities in Southern Arun Valley of Nepal Himalayas. PhD Thesis, University of Gauhati, India.

Kular, D.; Devakumar, D.; Manandhar, D.S.; Shrestha, B. P.; Saville, N. M. \& Osrin, D. (2013). Food security status in southern Nepal: Application of the Household Food Insecurity Access Scale questions. Proceedings of the Nutrition Society. 72: E314. doi:10.1017/S0029665113003480.

Lovendal, C.R. (2004). Food insecurity and vulnerability in Nepal: Profiles of seven vulnerable groups. Food Security and Agricultural Projects Analysis Service (ESAF) Working Paper no. 04-10, Rome: Agricultural and Development Economics Division, The Food and Agriculture Organization of the United Nations.

Maharjan, K.L. \& Joshi, N.P. (2011). Determinants of household food security in Nepal: A binary logistic regression analysis. Journal of Mountain Science. 8: 403-413, doi: 10.1007/s11629-011-2001-2. 
McDonald, C.M.; McLean, J.; Kroeun, H.; Talukder, A.; Lynd, L.D. \& Green, T.J. (2015).Household food insecurity and dietary diversity as correlates of maternal and child undernutrition in rural Cambodia. European Journal of Clinical Nutrition, 69:242-246. http://dx.doi.org/10.1038/ejcn.2014.161

MOHP, New ERA, \& ICF International(2012). Nepal Demographic and Health Survey 2011. Kathmandu: Ministry of Health and Population, Government of Nepal.

Onta, N. \& Resurreccion, B.P. (2011). The role of gender and caste in climate adaptation strategies in Nepal: Emerging change and persistent inequalities in the far-western region. Mountain Research and Development. 31(4):351356. doi: 10.1659/mrd-journal-d-10-00085.1.

Pandey, R. (2016). Human ecological Implications of climate change in the Himalaya: Investigating opportunities for adaptation in the Kaligandaki Basin, Nepal. PhD Thesis, the University of Adelaide, Australia.

Pandey, R. \& Adhikari, R. (2013). Nepalese migrant women worker and their socio-spatial exclusion: A study of Pokhara Valley. Unpublished research report submitted to University Grants Commission, Nepal.

Pandey, R. \& Bardsley, D.K. (2015).Social-ecological vulnerability to climate change in the Nepali Himalaya. Applied Geography. 46:74-86. doi:10.1016/j.apgeog.2015.09.008. Ramachandran, N. (2006). Women and food security in South Asia: Current issues and emerging concerns. UNUWIDER Research Paper no. 2006/131.

Regmi, H.R. (2007). Effect of unusual weather on cereal crop production and household food security.The Journal of Agriculture and Environment. 24:20-29. http://dx.doi.org/10.3126/aej.v8i0.723

Rijal, S.P.(2010-2011). Hardship in mountain livelihoods: Findings from Yari village, Humla district. The Geographical Journal of Nepal. 8:33-42.

Sen, A.K. (1981). Poverty and famines: An essay on entitlement and deprivation. Oxford: Clarendon Press.

Sen, A.K. (1984). Resources, values and development. Oxford: Basil Blackwell. 
Sen, A.K. (1989). Development as capability expansion. Journal of Development Planning. 19:41-58, reprinted in S Fukuda-Parr \& AK Shiva Kumar (eds), 2003 Readings in Human Development, Oxford University Press, New York, pp. 3-16.

Subedi, B.P. \& Pandey, R. (2002).Livelihood strategies of Rai communities in Arun Valley: Continuity and change. In R.P. Chaudhary, B.P. Subedi, O.R. Vetås\& T.H. Åse (eds.) Vegetation and society: their interaction in the Himalayas. Tribhuvan- Bergen Program, Tribhuvan University and University of Bergen, pp.157-170.

Subedi, B.P.; Subedi, V.R.; Dawadi, P.P. \& Pandey, R. (2007). Livelihood at Risk: Finding from Mid-western Nepal. Kathmandu: Informal Sector Service Centre (INSEC).

Uprety, Y.; Poudel, R.C.; Shrestha, K.K.; Rajbhandary, S.; Tiwari, N.N.; Shrestha, U.B. \&Asselin, H. (2012). Diversity of use and local knowledge of wild edible plant resources in Nepal. Journal of Ethnobiology and Ethnomedicine, 8:16. doi:10.1186/1746-4269-8-16.

USAID (1992). USAID policy determination: Definition of food security. Accessed on 06 October 2015 from<http://pdf. usaid.gov/pdf docs/Pnaav468.pdf.>

WB (2015a). Accesseđ on 17 July 2015 from $<$ http://povertydata.

worldbank.org/poverty/region/SAS>

WB (2015b). Accessed on 04 August 2015 from $<$ http://databank.worldbank.org/data//reports. aspx? source $=2 \&$ country $=$ NPL\&series $=$ \&period $=>$

WFS (1996). World Food Summit Plan of Action. Rome: World Food Summit (WFS).

Yu, B. \& You, L. (2013).A typology of food security in developing countries. China Agricultural Economic Review, 5(1):118 - 153 doi:10.1108/17561371311294810

\section{Annex:}

\section{Questions asked for HFIAS}

Answer scales for each questions: $0=$ no food deficiency, $1=$ rarely (once or twice in a month), $2=$ sometimes (three to ten times a month) and $4=$ often (more than ten times in a month).

1. In the past four weeks how often did you worry that your household would not have enough food?

2. In the past four weeks, how often were you or any household member not able to eat the kinds of food you preferred because of a lack of resources? 


\section{2| Rishikesh Pandey}

3. In the past four weeks, how often did you or any household member have to eat a limited variety of foods due to a lack of resources?

4. In the past four weeks, how often did you or any household member have to eat some foods that you really did not want to eat because of a lack of resources to obtain other types of food?

5. In the past four weeks, how often did you or any household member have to eat a smaller meal than you felt you needed because there was not enough food?

6. In the past four weeks, how often did you or any member have to eat fewer meals in a day because there was not enough food?

7. In the past four weeks, how often was there ever no food to eat of any kind in your household because of lack of resources to get food? 8. In the past four weeks, how often did you or any household member go to sleep at night hungry because there was not enough food?

9. In the past four weeks, how often did you or any household member go a whole day and night without eating anything because there was not enough food?

Pandey, Rishikesh PhD is an Environment and Development Geographer with one and a half decades of work experience in research and teaching in tertiary level, and management of community development programmes in Nepal. He obtained his $\mathrm{PhD}$ in Geography and Environment from the University of Adelaide, Australia. Dr Pandey is a co-author of two books. He has published some 20 research articles, some are under solo authorship while others are under joint authorship. Dr. Pandey is affiliated to Pokhara University, School of Development and Social Engineering, Nepal. His research interest focuses integration of social sciences with natural sciences to create dialogue between them and bridge the communication gap between the knowledge created by natural sciences and social sciences. Major fields of research includes: climate change and social ecosystem analysis; environmental health; agricultural ecology; natural process, disasters and human responses; livelihoods and food security; natural resource management and sustainable development; social exclusion/inclusion, human rights and democracy for development; gender and feminism; and many cross-cutting issues such as population ageing, labour migration, and youth and reproductive health.

Email: itsmehimalaya@gmail.com 